Baron, R., Martin, L., Gitsels-van der Wal, J.T., Noordman, J., Heymans, M.W., Spelten, E., Brugग J., Hutton, E.K. Health behaviour information provided to clients during midwife-led prenatal booking visits: findings from video analyses. Midwifery: 2017, 54(11), 7-17

\begin{tabular}{|l|l|}
$\begin{array}{l}\text { Postprint } \\
\text { Version }\end{array}$ & 1.0 \\
\hline Journal website & http://www.midwiferyjournal.com/article/S0266-6138(17)30104-3/fulltext \\
\hline Pubmed link & $\underline{\text { https://www.ncbi.nlm.nih.gov/pubmed/?term=28780476 }}$ \\
\hline DOI & $10.1016 /$ j.midw.2017.07.007 \\
\hline
\end{tabular}

This is a NIVEL certified Post Print, more info at http://www.nivel.eu

\title{
Health behaviour information provided to clients during midwife-led prenatal booking visits: Findings from video analyses.
}

Ruth Baron, PhD ${ }^{\mathrm{A}, *}$, Linda Martin, PhD ${ }^{\mathrm{A}}$, JANNEKe T. Gitsels-VAn DER WAL, PhD ${ }^{\mathrm{A}}$,

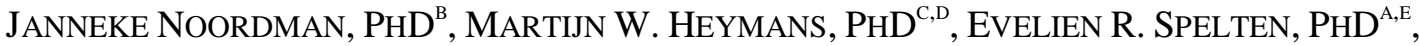
JOHANNES BRUG, PHD PROFESSOR ${ }^{C}$, EILEEN K. HUTTON, PHD PROFESSOR ${ }^{A, F}$

${ }^{a}$ Department of Midwifery Science, Midwifery Academy Amsterdam Groningen (AVAG), Amsterdam Public Health Research Institute, VU University Medical Centre, P.O. Box 7057, 1007 MB Amsterdam, The Netherlands

${ }^{\mathrm{b}}$ Netherlands Institute for Health Services Research (NIVEL), P.O. Box 1568, 3500 BN Utrecht, The Netherlands

${ }^{c}$ Department of Epidemiology and Biostatistics, Amsterdam Public Health Research Institute, VU University Medical Centre, P.O. Box 7057, 1007 MB Amsterdam, The Netherlands

d Department of Methodology and Applied Biostatistics, Faculty of Earth and Life Sciences, VU University Amsterdam, De Boelelaan 1085, 1081 HV Amsterdam, The Netherlands

${ }^{e}$ Department of Public Health, Rural Health School, La Trobe University, Melbourne, VIC 3086, Australia

' Department of Obstetrics and Gynecology, McMaster University, 1280 Main Street West, MDCL 2210, Hamilton, ON, Canada L8S 4K1

\section{HighLights}

- Basic to extensive information given about folic acid or smoking, when issue is relevant.

- Little prenatal information is provided on healthy nutrition and physical activity.

- Risks associated with certain health behaviours is emphasized more than benefits.

- Nulliparous women are provided somewhat more information than multiparous women.

\footnotetext{
AbSTRACT

Objective: to quantify to what extent evidence-based health behaviour topics relevant for pregnancy are discussed with clients during midwife-led prenatal booking visits and to assess the association of client characteristics with the extent of information provided.

Design: quantitative video analyses.

Setting and participants:
} 
Baron, R., Martin, L., Gitsels-van der Wal, J.T., Noordman, J., Heymans, M.W., Spelten, E., Brug⿹ J., Hutton, E.K. Health behaviour information provided to clients during midwife-led prenatal booking visits: findings from video analyses. Midwifery: 2017, 54(11), 7-17

173 video recordings of prenatal booking visits with primary care midwives and clients in the Netherlands taking place between August 2010 and April 2011. Measurements: thirteen topics regarding toxic substances, nutrition, maternal weight, supplements, and health promoting activities were categorized as either 'never mentioned', 'briefly mentioned', 'basically explained' or 'extensively explained'. Rates on the extent of information provided were calculated for each topic and relationships between client characteristics and dichotomous outcomes of the extent of information provided were assessed using Generalized Linear Mixed Modelling.

Findings: our findings showed that women who did not take folic acid supplementation, who smoked, or had a partner who smoked, were usually provided basic and occasionally extensive explanations about these topics. The majority of clients were provided with no information on recommended weight gain (91.9\%), fish promotion (90.8\%), caffeine limitation (89.6\%), vitamin D supplementation $(87.3 \%)$, physical activity promotion $(81.5 \%)$ and antenatal class attendance (75.7\%) and only brief mention of alcohol (91.3\%), smoking (81.5\%), folic acid (58.4) and weight at the start of pregnancy $(52.0 \%)$. The importance of a nutritious diet was generally either never mentioned $(38.2 \%)$ or briefly mentioned (45.1\%). Nulliparous women were typically given more information on most topics than multiparous women.

Key conclusions and implications for practice: although additional information was generally provided about folic acid and smoking, when relevant for their clients, the majority of women were provided with little or no information about the other health behaviours examined in this study. Midwives may be able to improve prenatal health promotion by providing more extensive health behaviour information to their clients during booking

\section{INTRODUCTION}

Suboptimal maternal nutrition, high pre-pregnancy weight and weight gain, low physical activity, and exposure to alcohol and tobacco are associated with unfavourable pregnancy outcomes, such as preterm births and intra-uterine growth restriction, as well as an increased likelihood of ill-health throughout life (Banderali et al., 2015; Bloomfield, 2011; Greenwood et al., 2014; Merkx et al., 2015; Pasternak et al., 2013; Pruett et al., 2013; Sanabria-Martinez et al., 2015; Starling et al., 2015). Education on nutrition and physical activity during pregnancy is associated with lower risk of adverse maternal health and pregnancy outcomes, such as excessive gestational weight gain, gestational diabetes, preterm birth and low birth weight (Girard and Olude, 2012; Gresham et al., 2014; Muktabhant et al., 2015; Oteng-Ntim et al., 2012; Sanabria-Martinez et al., 2015). Thus, pregnant women should be made aware of the impact of both beneficial and unfavourable health behaviours and encouraged and empowered to practice health promoting behaviours.

Midwives are considered to have an important role in promoting healthy behaviours during pregnancy (Beldon and Crozier, 2005; Biro, 2011). In the Netherlands, 85\% of women start their pregnancy under primary care provided by midwives (Stichting Perinatale Registratie Nederland, 2013). The prenatal booking visit usually takes 
Baron, R., Martin, L., Gitsels-van der Wal, J.T., Noordman, J., Heymans, M.W., Spelten, E., Brugh J., Hutton, E.K. Health behaviour information provided to clients during midwife-led prenatal booking visits: findings from video analyses. Midwifery: 2017, 54(11), 7-17

place at around 8 weeks of pregnancy, during which the midwife collects information about the medical and obstetric history of her client and family, performs physical examinations, and provides information relevant for pregnancy. The most recent Royal Dutch Organization of Midwives guideline on providing prenatal support and education advises midwives to discuss health behavioural topics with pregnant women during the prenatal booking visit (De Boer and Zeeman, 2008). This Dutch guideline advises midwives to determine the clients' Body Mass Index (BMI) at the start of pregnancy, to give advice on nutrition and physical activity depending on weight status and to discuss recommended weight gain during pregnancy, but does not specifically explain what information to give. There is an additional guideline on how to respond to and advise clients who smoke during pregnancy (i.e. Minimal Intervention Strategy for smoking cessation) (Partnership Stop met Roken, 2009). Guidelines from other countries, including the British NICE protocol (2008) and Australian Clinical Practice Guidelines (2012) (Australian Health Ministers' Advisory Council, 2012; National Collaborating Centre for Women's and Children's Health, 2008), as well as many studies give more detailed recommendations on what health care providers should discuss with their clients during various stages of their pregnancy.

Although guidelines and leaflets containing information about health behaviours are generally handed out to women during the prenatal booking visit in the Netherlands (Zwanger!, 2015), there is no best practice guideline in place with recommendations for midwives on what to convey to their clients about health behaviours. It is unclear what information is being discussed with clients during prenatal booking visits.

Some earlier studies from the Netherlands and other countries report that some health behaviour topics, such as alcohol consumption, physical activity and nutrition are minimally addressed by midwives during prenatal visits (Szwajcer et al., 2009; van der Wulp et al., 2013; Weir et al., 2010). In our previous interview study among pregnant women in prenatal primary care, most women believed that midwives tailored the amount of information they gave according to assessments of their clients' health and their prior knowledge based on some characteristics, such as their parity, their education, their weight status or appearing healthy (Baron et al., 2017). Many believed that this assessment had led to them not receiving much health education. There is, however, no empirical evidence demonstrating whether or not the amount of information provided to clients is associated with their characteristics. We aimed to assess the extent of information provided to clients by their midwives about various pregnancy-relevant health behaviour topics during their prenatal booking visit. We also aimed to explore any association of client characteristics (age, parity, education and BMI weight status) with the extent of information provided.

\section{METHODS}

\section{Study recruitment and population}

This current investigation is an observational video study undertaken as part of the DELIVER study. DELIVER, an acronym for Data EersteLIjns VERloskunde (translated as Data Primary Care Midwifery) was designed to examine the quality of prenatal primary care in the Netherlands (Mannien et al., 2012). Details on the design of the video study are reported elsewhere (Spelten et al., 2015). In brief, between August 2010 and April 2011, four of the twenty midwifery practices which had participated in the DELIVER study were invited to additionally have their clients' 
Baron, R., Martin, L., Gitsels-van der Wal, J.T., Noordman, J., Heymans, M.W., Spelten, E., Brugh J., Hutton, E.K. Health behaviour information provided to clients during midwife-led prenatal booking visits: findings from video analyses. Midwifery: 2017, 54(11), 7-17

prenatal booking visits video-recorded. These midwife practices were selected based on purposive sampling, which entailed taking into account their location and number of practicing midwives in the practice. These practices were first provided with written information and then visited in order to be provided with instructions about the various procedures. Participating midwives in these practices were asked to record ten to twenty visits each. Eligible clients who called the practices to make their first appointment were informed about the study and invited to participate in the video recording. Criteria for eligibility were being at least 18 years of age and able to understand Dutch or English.

Within these four midwifery practices, 229 clients of 352 (65.1\%) who were invited to participate, agreed to be video-recorded and provided informed consent, which stated they could withdraw from the study at any time. Of these 229 participants, 173 video recordings were suitable for analyses (see Fig. 1).

\section{[FIGURE 1]}

\section{DATA COLLECTION AND HANDLING}

Several measures were taken to ensure client confidentiality during video recordings (Van Dulmen et al., 2012). Prior to the start of each prenatal visit, an un-manned video camera was placed so that the midwife's full face could be seen. Clients and their partners (if present) could not be seen in a recognizable way (i.e. from behind, from the side, or not at all). Clients were given anonymous identification numbers, which were used to link the videotapes to the questionnaire data provided by midwives and clients. The videotapes were securely stored at the 'Communication Databank' of the Netherlands Institute for Health Services Research (NIVEL) (Van Dulmen et al., 2012).

For the current study, a database was created to collect information about the clients and to code the extent to which health behaviour topics were discussed during each prenatal visit, using Microsoft Office Access 2013. No distinction was made between midwife and client initiated discussion of a health behaviour topic, as it was not possible to determine if the midwife would have discussed the subject, had it not been broached by the client. The database with video data was finally converted into IBM SPSS version 22 for statistical analyses.

One-hundred and seventy-three videos (four midwife practices and 15 midwives) were assessed by RB using an assessment guide to categorize the extent of information given on each topic. To establish reliability LM and JG reassessed 30 videos each and these were subsequently compared.

\section{STUDY MEASURES}

\section{Dependent variables}

In order to determine which health behavioural topics were relevant to assess, we reviewed Dutch and international evidence-based guidelines, recent systematic reviews and the website of the Netherlands Nutrition Centre Foundation, a national agency for nutrition advice and education (http://www.voedingscentrum.nl) (Australian Health Ministers' Advisory Council, 2012; De Boer and Zeeman, 2008; EFSA Dietetic Products, Nutrition and Allergies (NDA), 2014; National Collaborating Centre for Women's and Children's Health, 2008). The following 
Baron, R., Martin, L., Gitsels-van der Wal, J.T., Noordman, J., Heymans, M.W., Spelten, E., Brugh J., Hutton, E.K. Health behaviour information provided to clients during midwife-led prenatal booking visits: findings from video analyses. Midwifery: 2017, 54(11), 7-17

dependent variables, i.e. health behaviour topics, were identified: Toxic substances: 'alcohol consumption', 'smoking', 'smoking in partner' and 'vitamin A limitation'; Nutrition: 'general nutritious diet', 'promotion of fish' and 'caffeine limitation'; Maternal weight: 'weight at start of pregnancy' and 'recommended weight gain'; Supplements: 'folic acid' and 'vitamin D'; Health promoting activities: 'physical activity promotion' and 'antenatal courses'. Each of these topics was scored based on the extent to which each was discussed, with four possible categories: 'never mentioned', 'briefly mentioned', 'basically explained', and 'extensively explained' (see Appendix A). Although every item was different, some consistency was sought in determining the criteria of each category. 'Never mentioned' was assigned if neither midwife nor client mentioned the topic during the video recording. The three categories 'briefly mentioned', 'basically explained' and 'extensively explained' generally followed a 'what', 'how (often/much/long)?' and 'why' structure. As an example, if folic acid was asked about using a close-ended question, such as 'are you taking folic acid?', it was coded as 'briefly mentioned'. 'Basically explained' generally entailed giving some explanation on how to carry out a behaviour, such as 'you can take folic acid until 10 weeks of pregnancy'. 'Extensively explained' was defined as explaining how, as well as why, a health behaviour should or should not be carried out, such as giving information about folic acid being protective against spina bifida.

Descriptive and Independent variables

Socio-demographics and information about the current pregnancy were obtained from questionnaires completed by the clients for an earlier study of these video recordings (Martin et al., 2013), as well as from the information exchange observed in the videos. Client questionnaires contained questions on the number of weeks they were pregnant, parity (dichotomized in 'nulliparous' or 'multiparous'), and their date of birth (age). Clients were asked about their highest attained educational level, categorized for this study into 'low/medium' (none, primary education, high school, lower/medium vocational education), or 'higher' (college/university). They were also asked about their country of birth, as well as that of their parents (ethnicity), categorized as 'Dutch' (respondent and both parents born in the Netherlands), or 'non-Dutch' (respondent or at least one parent born abroad) (Statistics Netherlands, 2015).

Socio-demographic information was also collected from the videos to check or add to the information from the questionnaires. Other independent variables obtained from the videos were whether or not clients were taking folic acid, drinking alcohol during pregnancy, whether they or their partner were smoking during pregnancy, and the clients' height and pre-pregnancy weight to calculate their Body Mass Index (BMI). If pre-pregnancy weight was not mentioned or unknown, but the client was weighed at the midwife practice, that current weight was used to calculate BMI. BMI was subsequently classified as underweight', 'normal weight', 'overweight' and 'obese'. For the regression analyses, BMI was dichotomized into 'not overweight' versus 'overweight/obese'.

\section{STATISTICAL ANALYSES}

We used quadratic weighted kappa using Altman's (1991) assessment of agreement scores, to assess the interrater reliability of each observed item in the 60 videos that 
Baron, R., Martin, L., Gitsels-van der Wal, J.T., Noordman, J., Heymans, M.W., Spelten, E., Brugh J., Hutton, E.K. Health behaviour information provided to clients during midwife-led prenatal booking visits: findings from video analyses. Midwifery: 2017, 54(11), 7-17

were analysed separately by two other researchers independently (30 each) (Altman, 1991).

Descriptive statistics were used to report socio-demographic and health characteristics of the clients. Frequencies of the four discussion categories of each health behaviour topic were calculated for an overall description of the extent of information provided. Frequencies were also calculated for the four categories of discussing folic acid, smoking and smoking in partner, in subgroups of clients who did not take folic acid, who smoked, or whose partner smoked, respectively. Before assessing the relationships between client characteristics (independent variables) and the extent of information provided on each topic (dependent variables), we calculated per item, the intra-class correlation coefficients (ICC) for midwives and practices to assess the degree of correlation within midwives and within practices. As there was evidence of some correlation, multilevel binomial logistic regression was conducted for each relationship, using Generalized Linear Mixed Modelling (GLMM), adjusting for the two levels practice and midwife. As some topics were part of a standard digital checklist (i.e. smoking and alcohol consumption) and others were not (i.e. recommended weight gain and fish promotion), we dichotomized each topic in this study in two ways: 'never mentioned' versus 'briefly mentioned/basically explained/extensively explained' and 'never mentioned/briefly mentioned' versus 'basically explained/extensively explained'. Odds ratios and 95\% confidence intervals were reported to portray these relationships.

\section{FINDINGS}

\section{Characteristics of sample and interrater reliability}

Per practice 2-5 midwives recorded their prenatal visits, and on average each midwife recorded 11.5 (range 6-20) visits. The average client age in our study was 29 years old, $51.4 \%$ were nulliparous, $46.2 \%$ were of higher education and $22.0 \%$ were of non-Dutch ethnicity (Table 1). The median weeks of pregnancy was 8 at the time of the video recording. In our study, $14.5 \%$ reported smoking during pregnancy, $35.6 \%$ had a partner that smoked, $11.5 \%$ had not taken any folic acid supplementation, $38.2 \%$ were overweight/obese at the start of their pregnancy and $0.6 \%$ reported some alcohol consumption since knowing they were pregnant.

\section{[TABLE 1]}

The median ICC was 0.15 (range $0-0.50$ ) for midwives and 0.15 (range $0-0.64$ ) for practice, indicating various levels of data correlation within midwives and practices, with respect to the extent of information given. The quadratic weighted kappa values determining the interrater reliability ranged between 0.52 (moderate) and 0.82 (very good), with the majority (12/13) of weighted kappa values representing 'good' agreement (alcohol, nutritious diet, weight at start of pregnancy, fish promotion, smoking, smoking in partner, folic acid, recommended weight gain) to 'very good' agreement (physical activity promotion, caffeine limitation, vitamin D, vitamin A limitation) (Altman, 1991).

\section{Health behaviour topics; extent of information provision}

At least $75 \%$ of all clients were provided with no information on recommended weight gain, fish consumption promotion, caffeine limitation, vitamin D supplementation, physical activity promotion and antenatal class attendance (Table 
Baron, R., Martin, L., Gitsels-van der Wal, J.T., Noordman, J., Heymans, M.W., Spelten, E., Brugh J., Hutton, E.K. Health behaviour information provided to clients during midwife-led prenatal booking visits: findings from video analyses. Midwifery: 2017, 54(11), 7-17

2). Topics which were briefly mentioned in most videos were alcohol and smoking. Folic acid was mentioned briefly in just over half the visits and minimal explanations were given in just over another quarter of the visits. In about one third of the visits, general nutritious diet was never discussed; in just under half the visits, it was briefly mentioned and in the remaining videos it was basically discussed. For vitamin A, the proportions 'never mentioned', 'briefly mentioned', 'basically explained' comprised about one third of the visits each. Extensive explanations were rarely given about any topic.

\section{[TABLE 2]}

Some secondary results, which became apparent during the video analyses and development of the assessment guide, were that certain health behaviours important for pregnancy, were often discussed with respect to their risks, but not to promote their practice. Fruit and vegetable consumption, for instance, was often mentioned during the visits in terms of the need to wash them well and to make sure they were not out-of-date before eating, but not in terms of promoting the recommended intake. Similarly, fish consumption was often discussed in the context of needing to be careful with raw fish and avoiding vacuum-packed fish, but the benefits of regular fish consumption were not discussed and fish intake was not promoted. If physical activity was mentioned, it was usually in terms of it being fine to continue exercising, that clients had to listen to their own body and slow down if they experienced complaints, but again, not to actually promote physical activity.

\section{Associations of health behaviour topic discussion with client characteristics}

If a client did not take folic acid, smoked or had a smoking partner, a basic explanation would usually, and extensive explanation occasionally, be given about these behaviours. Basic and extensive explanations respectively, were provided as follows: not taking folic acid: 50\%, 16.7\%; smoking: $79.2 \%, 12.5 \%$; smoking in partner: $90.2 \%, 3.1 \%$ (Table 3). Although little or no information was given to all women on most topics, nulliparous women were given significantly more information than multiparous women for recommended weight gain, general nutritious diet, limiting vitamin A, pre-pregnancy weight and antenatal class attendance (Table 4). Low/medium education was associated with at least some promotion of fish consumption, more information about antenatal classes and folic acid supplementation. Being overweight or obese was associated with more explanation about limiting vitamin A and less explanation about antenatal class attendance, but not associated with discussion of any nutritional topics, supplements, weight at the beginning of pregnancy, recommended weight gain, or physical activity.

\section{[TABLE 3][TABLE 4]}

\section{DISCUSSION}

\section{Main findings}

In this study we aimed to assess the extent of information provision on relevant health behaviours to clients by midwives during prenatal booking visits, as well their association with client characteristics. Topics were typically either 'never mentioned' or 'briefly mentioned', with at times basic explanations on folic acid, vitamin A, 
Baron, R., Martin, L., Gitsels-van der Wal, J.T., Noordman, J., Heymans, M.W., Spelten, E., Brugg J., Hutton, E.K. Health behaviour information provided to clients during midwife-led prenatal booking visits: findings from video analyses. Midwifery: 2017, 54(11), 7-17

nutritious diet, and weight at the start of pregnancy. Clients were rarely provided with more extensive explanations about any topics. Topics which were generally 'never mentioned' were recommended weight gain, benefits of fish consumption, caffeine limitation, vitamin D supplementation, benefits of physical activity, and antenatal class attendance. Fruit and vegetable consumption, fish intake and physical activity tended to be discussed with the focus on avoiding the possible risks associated with these health behaviours, rather than on promoting their benefits. Clients who did not take folic acid supplements, who smoked, or had a partner who smoked were given basic explanations and occasionally more extensive explanations about the relevant health topic. Nulliparous women were more likely to be given more information on most health behaviour topics than multiparous women, but there were generally few notable differences in the extent of information provided to women across other client characteristics.

\section{Extent of information provision}

Our study showed that little to no information was provided to clients about many pregnancy-relevant health behaviour topics. Fruit and vegetable consumption, for instance, was usually not promoted, but mainly discussed in terms of avoiding infectious diseases (which is discussed thoroughly in an earlier study of the same sample (Pereboom et al., 2014)). Other studies have also reported that nutritional advice given to pregnant women tends to focus more on food safety, such as avoiding food poisoning or infections (Garnweidner et al., 2013; Szwajcer et al., 2009). It has been reported, however, that many pregnant women are not meeting the recommended requirements of vegetable and fruit consumption (Wen et al., 2010; Wilkinson et al., 2009). Fish intake and physical activity also tend to decline during pregnancy (Bloomingdale et al., 2010; Clarke and Gross, 2004; Oken et al., 2003), suggesting that more information should be given about the benefits of healthy nutrition and physical activity. Discussing the potential risks, rather than the health promoting properties of nutrition and physical activity may lead to a lower rather than higher practice of these health behaviours (Bloomingdale et al., 2010; Lucas et al., 2015; Oken et al., 2003; Stengel et al., 2012). Placing more emphasis on their contribution to health gain may encourage more pregnant women to practice these health behaviours.

\section{Association with client characteristics}

In our study, clients who were not taking folic acid supplements typically were given some explanation about the timeframe in which to take folic acid and at times, why it was important; similarly clients and their partners who reported smoking were given more information about the consequences of smoking, and advice on smoking reduction or cessation. This shows that midwives respond to some specific health needs of their clients, by providing more tailored information and resources. As the women in our earlier interview study had perceived (Baron et al., 2017), multiparous women were provided with less information than nulliparous women about various health behaviour topics, but many of these topics were minimally discussed with nulliparous women as well. Besides parity, there were generally few notable associations of client characteristics with the extent of information provided. For instance, women who were overweight or obese in our study, did not receive more information about nutrition, recommended weight gain, or physical activity. Earlier studies have shown pre-pregnancy overweight and obesity to be associated with 
Baron, R., Martin, L., Gitsels-van der Wal, J.T., Noordman, J., Heymans, M.W., Spelten, E., Brugh J., Hutton, E.K. Health behaviour information provided to clients during midwife-led prenatal booking visits: findings from video analyses. Midwifery: 2017, 54(11), 7-17

lower fruit and vegetable intake, increased sugar and fat intake, and less physical activity (de Jersey et al., 2013; Shin et al., 2016), suggesting that eating patterns and exercise should ideally be discussed and advice given by midwives, taking Body Mass Index (BMI) into account. An interview study with obese and overweight women revealed that although they were aware that healthy nutrition and physical activity were beneficial for pregnancy, they were not able to name any specific reasons why (Sui et al., 2013), suggesting that explanations should be given about why certain health behaviours are beneficial for pregnancy. Women in general may be more likely to follow recommendations, if explanations are given about why they are important (Lucas et al., 2014).

Although almost all women were asked by their midwives whether they were drinking alcohol during pregnancy, only one woman in our study responded that she did so. Other studies in the Netherlands have estimated any alcohol consumption during pregnancy to be about 20\% and 50\% (Advies Stuurgroep Zwangerschap en Geboorte (Advisory Committee on Pregnancy and Childbirth), Dec 2009; Lanting et al., 2015). It may be that too few opportunities for alcohol consumption had occurred by the time the visit took place in our study (median 8 weeks), but women may also have under-reported their alcohol consumption, as has been reported in other studies (Crawford-Williams et al., 2015; van der Wulp et al., 2013). This advocates explaining possible risks of even small amounts of alcohol to all pregnant women. In another study, women reported that the relaxed attitude of their health care providers towards alcohol, led to them to believe alcohol was probably not that harmful (Meurk et al., 2014). This implies that midwives should not underestimate the possible effects their own attitudes and messages regarding various health behaviours have on their clients.

\section{Health education by midwives}

The amount of information about various health behaviours that clients were given correlated somewhat within practices and within midwives, probably due to different attitudes, policies and procedures between midwives and practices towards promoting healthy behaviours. Efforts should be undertaken to enable all clients to be provided with this pregnancy-relevant information, and if possible, tailored to their specific needs.

There are several reasons why midwives may not discuss health behaviour topics more extensively. Routinely advising all pregnant women to take vitamin $\mathrm{D}$, for instance, is still controversial, due to differing recommendations between the Royal Dutch Organization of Midwives and the Health Council of the Netherlands (De Boer and Zeeman, 2008; Health Council of the Netherlands, 2008). Prenatal heath care providers may not always agree with weight gain recommendations, or feel that weight and weight gain are issues potentially too sensitive to discuss with their clients, as has been reported in studies outside of the Netherlands (Stotland et al., 2010; Whitaker et al., 2016). A previous interview study with midwives in the Netherlands on discussing alcohol revealed that, besides not always believing small amounts of alcohol would be harmful, some did not believe they had the right screening skills to identify women who drank alcohol, nor that they had sufficient knowledge on the adverse effects of alcohol (van der Wulp et al., 2013). Midwives may also feel that time constraints, or lack of self-efficacy in providing health promotion prevent them from spending more time and effort on health education (Stotland et al., 2010; Whitaker et al., 2016). The booking visit already consists of 
Baron, R., Martin, L., Gitsels-van der Wal, J.T., Noordman, J., Heymans, M.W., Spelten, E., Brugh J., Hutton, E.K. Health behaviour information provided to clients during midwife-led prenatal booking visits: findings from video analyses. Midwifery: 2017, 54(11), 7-17

many components besides health behaviour education, including collecting sociodemographic and medical information, prenatal anomaly counselling, as well as physical examinations, such as taking blood pressure, a blood sample and listening to the foetal heartbeat.

In the general population, including patients in primary care, there is varying evidence for the effect of interventions, such as health education on health behaviours (Eden et al., 2002; Nichols, 1994; Pignone et al., 2003; Vahamiko et al., 2013). It is generally accepted that people need motivation, abilities and opportunities for health behaviour change in order to make meaningful and lasting changes; good-quality health education may help to strengthen motivation and abilities (Brug, 2008). Although pregnant women may also experience barriers to healthy nutrition and physical activity, because of pregnancy complaints (Coad et al., 2002), they do tend to be more motivated to change their behaviours than nonpregnant people, due to knowing their health behaviours can also affect their unborn child (Edvardsson et al., 2011). When pregnant, women tend to reduce smoking, alcohol and caffeine intake, and most women in high income countries take folic acid supplementation, suggesting that women do respond to established pregnancy guidelines and are able to make changes, even to addictive habits (Crozier et al., 2009). However, Crozier et al. (2009) reported that fruit and vegetable intake do not tend to change from before to during pregnancy, suggesting that fruit and vegetable consumption are not emphasized enough in prenatal health education. Some evidence suggests that promoting increased fish and fruit/vegetable consumption and exercise during early pregnancy can influence the nutritional and physical activity behaviours of pregnant women (Bosaeus et al., 2015; Whitaker et al., 2016), as well as decrease the risk of suboptimal maternal health and pregnancy outcomes (Girard and Olude, 2012; Gresham et al., 2014; Muktabhant et al., 2015; Oteng-Ntim et al., 2012; Sanabria-Martinez et al., 2015). Pregnant women in an earlier interview study reported that the nutritional advice given to them by their prenatal care providers, influenced their own diets (Whitaker et al., 2016). If extensive heath education does not have a notable impact on actual health behaviours, it should at least be a basic requirement of prenatal care, to ensure that women are well informed about the best possible health behaviours for their pregnancy and child.

Further research should explore midwives' experiences with, and the facilitators and barriers with respect to providing health education. It would be worthwhile to reexamine how prenatal visits could be structured to avoid an overload of information during the booking visit. The development of a standardized guideline for midwives with specific advice on what health behaviour information to convey to their clients may facilitate prenatal health education. Further research should also investigate how much influence extensive health education has on pregnant women's actual health behaviours, both during and after pregnancy.

\section{STRENGTHS AND LIMITATIONS}

This is the first study, as far as we know, which assesses the information provided to clients on a wide range of pregnancy-relevant health behaviours within actual midwife-client settings, giving a unique and perhaps more accurate portrayal of real life than self-reported assessments would.

The assessment guide was not a pre-validated instrument, but was created as a means to quantify the extent of information for the current study. The interrater reliability 
Baron, R., Martin, L., Gitsels-van der Wal, J.T., Noordman, J., Heymans, M.W., Spelten, E., Brugh J., Hutton, E.K. Health behaviour information provided to clients during midwife-led prenatal booking visits: findings from video analyses. Midwifery: 2017, 54(11), 7-17

was reasonably high for most items, indicating that the chosen categories were feasible and interpreted quite consistently by different experts.

Video recordings of actual midwife-client consultations could potentially lead to midwives and clients altering their behaviours while knowing they are being filmed, affecting the internal validity of the study (Coleman, 2000). The midwives in our study did not know which aspects of the visit would be examined, however, increasing the likelihood of carrying out care as usual. Clients were also informed that the research focused on their midwives' performance, not on their own behaviours, making the possibility that they modified their own behaviours less likely. The relatively high proportion of clients willing to participate, after being informed about the study $(65.1 \%)$, suggests that the majority of clients did not consider the video camera to be intrusive. An earlier review of video recordings of physician-patient interactions also concluded that being filmed did not have much effect on the behaviours of physicians or patients (Themessl-Huber et al., 2008). Our sample size was large for a video study, but with 173 clients of four practices and 15 midwives, both clients and midwives may not have fully represented the general population, or they may have differed in relevant ways to those who chose not to participate in the study, affecting the external validity (Coleman, 2000). However, the socio-demographics were quite comparable to the general Dutch population of women. Compared to the population of pregnant women in 2010, there were somewhat more nulliparous women in our study (51.4\% versus $47.5 \%)$ and they were somewhat younger (mean 29 versus 31 years of age) (Stichting Perinatale Registratie Nederland, 2013). Our study consisted of more highly educated women (46.2\%), but contained a similar proportion of non-Dutch ethnicity $(22.0 \%)$ compared to the 2010 reproductive population of women in the Netherlands $(28.2 \%$ and $22.7 \%$ respectively) (Statistics Netherlands, 2010). It is also plausible that midwives who were confident about the way they provided prenatal health care were more likely to participate in this type of study; our results may therefore overestimate rather than underestimate the extent of health education in primary prenatal health care.

\section{CONCLUSION}

Women who did not take folic acid, who smoked or had a partner who smoked, were typically provided basic and occasionally more extensive information about these topics during the prenatal booking visit. However, little or no information was given to all women for most other pregnancy-relevant health behavioural topics about how to carry out various health behaviours and why these behaviours were important for healthy maternal and pregnancy outcomes; there was a greater focus on the risks than on the benefits of various health behaviours. Midwives may be able to improve prenatal health promotion by providing more extensive health behaviour information to their clients during booking visits. The development of a guideline for midwives with specific information on what to convey to clients about health behaviours may be beneficial.

\section{CONFLICT OF INTEREST(S)}

The authors declare no competing interests. 
Baron, R., Martin, L., Gitsels-van der Wal, J.T., Noordman, J., Heymans, M.W., Spelten, E., Brugग J., Hutton, E.K. Health behaviour information provided to clients during midwife-led prenatal booking visits: findings from video analyses. Midwifery: 2017, 54(11), 7-17

\section{ETHICAL APPROVAL}

This study was approved by the Institutional Review Board and the Medical Ethical Committee of the VU university medical centre, Amsterdam on December 9th, 2009 (Ref. 2009/284).

\section{FUNDING SOURCES}

This research did not receive any specific grant from funding agencies in the public, commercial, or not-for-profit sectors.

\section{Clinical Trial Registry AND Registration nUMber (IF APPLICABLE) \\ Not applicable.}

\section{REFERENCES}

Advies Stuurgroep Zwangerschap en Geboorte, 2009. (Advisory Committee on Pregnancy and Childbirth) (Ed.) Dec. Een Goed Begin; Veilige Zorg Rond Zwangerschap En Geboorte (A Good Beginning; Safe Care during Pregnancy and Birth)., Utrecht.

Altman, D., 1991. Practical Statistics for Medical Research. Chapman and Hall, London.

Australian Health Ministers' Advisory Council, 2012. Clinical Practice Guidelines: Antenatal Care-module 1.

Banderali, G., Martelli, A., Landi, M., Moretti, F., Betti, F., Radaelli, G., Lassandro, C., Verduci, E., 2015. Short and long term health effects of parental tobacco smoking during pregnancy and lactation: a descriptive review. Journal of Translational Medicine 13, (0150690-y).

Baron, R., Heesterbeek, Q., Mannien, J., Hutton, E.K., Brug, J., Westerman, M.J., 2017. Exploring health education with midwives, as perceived by pregnant women in primary care: a qualitative study in the Netherlands. Midwifery 46, 37-44.

Beldon, A., Crozier, S., 2005. Health promotion in pregnancy: the role of the midwife. The journal of the Royal Society for the Promotion of Health 125, 216-220.

Biro, M.A., 2011. What has public health got to do with midwifery? Midwives' role in securing better health outcomes for mothers and babies. Women and Birth: Journal of the Australian College of Midwives 24, 17-23.

Bloomfield, F.H., 2011. How is maternal nutrition related to preterm birth? Annual Review of Nutrition 31, 235-261.

Bloomingdale, A., Guthrie, L.B., Price, S., Wright, R.O., Platek, D., Haines, J., Oken, E., 2010. A qualitative study of fish consumption during pregnancy. The American Journal of Clinical Nutrition 92, 1234-1240.

Bosaeus, M., Hussain, A., Karlsson, T., Andersson, L., Hulthen, L., Svelander, C., Sandberg, A.S., Larsson, I., Ellegard, L., Holmang, A., 2015. A randomized longitudinal dietary intervention study during pregnancy: effects on fish intake, phospholipids, and body composition. Nutrition Journal 14 (1), (2891-14-1).

Brug, J., 2008. Determinants of healthy eating: motivation, abilities and environmental opportunities. Family Practice 25 (Suppl. 1), Si50-S55.

Clarke, P.E., Gross, H., 2004. Women's behaviour, beliefs and information sources about physical exercise in pregnancy. Midwifery 20, 133-141.

Coad, J., Al-Rasasi, B., Morgan, J., 2002. Nutrient insult in early pregnancy. The Proceedings of the Nutrition Society 61, 51-59.

Coleman, T., 2000. Using video-recorded consultations for research in primary care: advantages and limitations. Family Practice 17, 422-427.

Crawford-Williams, F., Steen, M., Esterman, A., Fielder, A., Mikocka-Walus, A., 2015. "My midwife said that having a glass of red wine was actually better for the baby": a focus group study of women and their partner's knowledge and experiences relating to alcohol consumption in pregnancy. BMC Pregnancy and Childbirth 15, 015-0506-3. 
Baron, R., Martin, L., Gitsels-van der Wal, J.T., Noordman, J., Heymans, M.W., Spelten, E., Brugg, J., Hutton, E.K. Health behaviour information provided to clients during midwife-led prenatal booking visits: findings from video analyses. Midwifery: 2017, 54(11), 7-17

Crozier, S.R., Robinson, S.M., Godfrey, K.M., Cooper, C., Inskip, H.M., 2009. Women's dietary patterns change little from before to during pregnancy. The Journal of Nutrition 139, 1956-1963.

De Boer, J., Zeeman, K., 2008. Prenatale verloskundige begeleiding, aanbevelingen voor ondersteuning, interactie en voorlichting. KNOV-standaard (Prenatal midwife care, recommendations for support, interaction and education. Royal Dutch Organization of Midwives).

van der Wulp, N.Y., Hoving, C., de Vries, H., 2013. A qualitative investigation of alcohol use advice during pregnancy: experiences of Dutch midwives, pregnant women and their partners. Midwifery 29, e89-e98.

Eden, K.B., Orleans, T., Mulrow, C.D., Pender, N.J., Teutsch, S.M., 2002. Does counseling by clinicians improve physical activity? A summary of the evidence for the U.S. Preventive Services Task Force. Annals of Internal Medicine 137(3), 208-215.

Edvardsson, K., Ivarsson, A., Eurenius, E., Garvare, R., Nystrom, M.E., Small, R., Mogren, I., 2011. Giving offspring a healthy start: parents' experiences of health promotion and lifestyle change during pregnancy and early parenthood. BMC Public Health 11, 2458-11936.

EFSA Dietetic Products, Nutrition and Allergies (NDA), 2014. Scientific Opinion on Health benefits of seafood (fish and shellfish) consumption in relation to health risks associated with exposure to methylmercury. European Food Safety Authority (EFSA) Journal 12, 3761.

Garnweidner, L.M., Sverre Pettersen, K., Mosdol, A., 2013. Experiences with nutritionrelated information during antenatal care of pregnant women of different ethnic backgrounds residing in the area of Oslo, Norway. Midwifery 29, e130-e137.

Girard, A.W., Olude, O., 2012. Nutrition education and counselling provided during pregnancy: effects on maternal, neonatal and child health outcomes. Paediatric and Perinatal Epidemiology 26 (Suppl. 1), S191-S204.

Greenwood, D.C., Thatcher, N.J., Ye, J., Garrard, L., Keogh, G., King, L.G., Cade, J.E., 2014. Caffeine intake during pregnancy and adverse birth outcomes: a systematic review and dose-response meta-analysis. European Journal of Epidemiology 29, 725-734.

Gresham, E., Byles, J.E., Bisquera, A., Hure, A.J., 2014. Effects of dietary interventions on neonatal and infant outcomes: a systematic review and meta-analysis. The American Journal of Clinical Nutrition 100, 1298-1321.

Health Council of the Netherlands, 2008. Towards an Adequate Intake of Vitamine D. The Hague: Health Council of the Netherlands. Publication no. 2008/15E. ISBN 978-90-5549729-4.

de Jersey, S.J., Nicholson, J.M., Callaway, L.K., Daniels, L.A., 2013. An observational study of nutrition and physical activity behaviours, knowledge, and advice in pregnancy. BMC Pregnancy and Childbirth 13, (2393-13-115).

Lanting, C.I., van Dommelen, P., van der Pal-de Bruin, K.M., Bennebroek Gravenhorst, J., van Wouwe, J.P., 2015. Prevalence and pattern of alcohol consumption during pregnancy in the Netherlands. BMC Public Health 15, 015-2070-1.

Lucas, C., Charlton, K.E., Yeatman, H., 2014. Nutrition advice during pregnancy: do women receive it and can health professionals provide it? Maternal and Child Health Journal 18, 2465-2478.

Lucas, C., Starling, P., McMahon, A., Charlton, K., 2016. Erring on the side of caution: pregnant women's perceptions of consuming fish in a risk averse society. Journal of Human Nutrition and Dietetics: The Official Journal of the British Dietetic Association 29 (4), 418-426.

Mannien, J., Klomp, T., Wiegers, T., Pereboom, M., Brug, J., de Jonge, A., van der Meijde, M., Hutton, E., Schellevis, F., Spelten, E., 2012. Evaluation of primary care midwifery in The Netherlands: design and rationale of a dynamic cohort study (DELIVER). BMC Health Services Research 12, 69.

Martin, L., Van Dulmen, S., Spelten, E., De Jonge, A., De Cock, P., Hutton, E., 2013. Prenatal counseling for congenital anomaly tests: parental preferences and perceptions of midwife performance. Prenatal Diagnosis 33, 341-353. 
Baron, R., Martin, L., Gitsels-van der Wal, J.T., Noordman, J., Heymans, M.W., Spelten, E., Brugg, J., Hutton, E.K. Health behaviour information provided to clients during midwife-led prenatal booking visits: findings from video analyses. Midwifery: 2017, 54(11), 7-17

Merkx, A., Ausems, M., Bude, L., de Vries, R., Nieuwenhuijze, M.J., 2015. Weight gain in healthy pregnant women in relation to pre-pregnancy BMI, diet and physical activity. Midwifery 31, 693-701.

Meurk, C.S., Broom, A., Adams, J., Hall, W., Lucke, J., 2014. Factors influencing women's decisions to drink alcohol during pregnancy: findings of a qualitative study with implications for health communication. BMC Pregnancy and Childbirth 14, (2393-14-246).

Muktabhant, B., Lawrie, T.A., Lumbiganon, P., Laopaiboon, M., 2015. Diet or exercise, or both, for preventing excessive weight gain in pregnancy. The Cochrane Database of Systematic Reviews 6, (CD007145. doi, CD007145).

National Collaborating Centre for Women's and Children's Health, 2008. Antenatal care, routine care for the healthy pregnant woman, NICE Clinical Guidelines No.62, London.

Nichols, J.L., 1994. Changing public behavior for better health: is education enough?

American Journal of Preventive Medicine 10, 19-22.

Oken, E., Kleinman, K.P., Berland, W.E., Simon, S.R., Rich-Edwards, J.W., Gillman, M.W., 2003. Decline in fish consumption among pregnant women after a national mercury advisory. Obstetrics and Gynecology 102, 346-351.

Oteng-Ntim, E., Varma, R., Croker, H., Poston, L., Doyle, P., 2012. Lifestyle interventions for overweight and obese pregnant women to improve pregnancy outcome: systematic review and meta-analysis. BMC Medicine 10, (7015-10-47).

Partnership Stop met Roken, 2009. Richtlijn Behandeling van Tabaksverslaving herziening (Guideline for treating tobacco addiction revised). Dutch Institute for Healthcare Improvement (CBO), Utrecht.

Pasternak, Y., Aviram, A., Poraz, I., Hod, M., 2013. Maternal nutrition and offspring's adulthood NCD's: a review. The Journal of Maternal-fetal Neonatal Medicine: The Official Journal of the European Association of Perinatal Medicine, the Federation of Asia and Oceania Perinatal Societies, the International Society of Perinatal Obstetricians 26, 439444.

Pereboom, M.T., Mannien, J., van Almkerk, K.D., Spelten, E.R., Gitsels, J.T., Martin, L., Hutton, E.K., Schellevis, F.G., 2014. What information do Dutch midwives give clients about toxoplasmosis, listeriosis and cytomegalovirus prevention? An exploratory study of videotaped consultations. Patient Education and Counseling 96, 29-35.

Pignone, M.P., Ammerman, A., Fernandez, L., Orleans, C.T., Pender, N., Woolf, S., Lohr, K.N., Sutton, S., 2003. Counseling to promote a healthy diet in adults: a summary of the evidence for the U.S. Preventive Services Task Force. American Journal of Preventive Medicine 24, 75-92.

Pruett, D., Waterman, E.H., Caughey, A.B., 2013. Fetal alcohol exposure: consequences, diagnosis, and treatment. Obstetrical Gynecological Survey 68, 62-69.

Sanabria-Martinez, G., Garcia-Hermoso, A., Poyatos-Leon, R., Alvarez-Bueno, C., SanchezLopez, M., Martinez-Vizcaino, V., 2015. Effectiveness of physical activity interventions on preventing gestational diabetes mellitus and excessive maternal weight gain: a metaanalysis. BJOG: An International Journal of Obstetrics and Gynaecology 122, 1167-1174.

Shin, D., Lee, K.W., Song, W.O., 2016. Pre-Pregnancy Weight Status Is Associated with Diet Quality and Nutritional Biomarkers during Pregnancy. Nutrients 8. http://dx.doi.org/10.3390/nu8030162.

Spelten, E.R., Martin, L., Gitsels, J.T., Pereboom, M.T., Hutton, E.K., van Dulmen, S., 2015. Introducing video recording in primary care midwifery for research purposes: procedure, dataset, and use. Midwifery 31, 95-102.

Starling, P., Charlton, K., McMahon, A.T., Lucas, C., 2015. Fish intake during pregnancy and foetal neurodevelopment-a systematic review of the evidence. Nutrients 7, 2001-2014.

Statistics Netherlands, 2010.

〈http://statline.cbs.nl/StatWeb/publication/?DM=SLNL\&PA $=71822$ NED\&D1 $=0 \& D 2=\mid \& D 3=0$, 4-5\&D4=0-R. Baron et al. Midwifery 54 (2017) 7-17 16 $4 \& D 5=a \& D 6=0 \& D 7=9 \& H D R=T, G 2, G 1, G 5, G 6 \& S T B=G 4, G 3 \& V W=T\rangle$.

Statistics Netherlands, 2015. 〈http://www.cbs.nl/nl-NL/menu/methoden/begrippen/ default.htm?ConceptID=37). (Consulted January 2015).

Stengel, M.R., Kraschnewski, J.L., Hwang, S.W., Kjerulff, K.H., Chuang, C.H., 2012. "What my doctor didn't tell me": examining health care provider advice to overweight and obese 
Baron, R., Martin, L., Gitsels-van der Wal, J.T., Noordman, J., Heymans, M.W., Spelten, E., Brugg J., Hutton, E.K. Health behaviour information provided to clients during midwife-led prenatal booking visits: findings from video analyses. Midwifery: 2017, 54(11), 7-17

pregnant women on gestational weight gain and physical activity. Women's Health Issues: Official Publication of the Jacobs Institute of Women's Health 22, e535-e540.

Stichting Perinatale Registratie Nederland, 2013.

〈http://www.perinatreg.nl/uploads/150/153/PRN_jaarboek_2013_09122014.pdf〉.

Stotland, N.E., Gilbert, P., Bogetz, A., Harper, C.C., Abrams, B., Gerbert, B., 2010.

Preventing excessive weight gain in pregnancy: how do prenatal care providers approach counseling? Journal of Women's Health 19, 807-814.

Sui, Z., Turnbull, D.A., Dodd, J.M., 2013. Overweight and obese women's perceptions about making healthy change during pregnancy: a mixed method study. Maternal and Child Health Journal 17, 1879-1887.

Szwajcer, E.M., Hiddink, G.J., Koelen, M.A., van Woerkum, C.M., 2009. Written nutrition communication in midwifery practice: what purpose does it serve? Midwifery 25, 509-517.

Themessl-Huber, M., Humphris, G., Dowell, J., Macgillivray, S., Rushmer, R., Williams, B., 2008. Audio-visual recording of patient-GP consultations for research purposes: a literature review on recruiting rates and strategies. Patient Education and Counseling 71, 157-168.

Vahamiko, S., Isolauri, E., Poussa, T., Laitinen, K., 2013. The impact of dietary counselling during pregnancy on vitamin intake and status of women and their children. International Journal of Food Sciences and Nutrition 64, 551-560.

Van Dulmen, S., Humphris, G., Eide, H., 2012. Towards a guideline for person-centered research in clinical communication: lessons learned from three countries. International Journal of Person-Centered Medicine 2, 58-63.

Weir, Z., Bush, J., Robson, S.C., McParlin, C., Rankin, J., Bell, R., 2010. Physical activity in pregnancy: a qualitative study of the beliefs of overweight and obese pregnant women. BMC Pregnancy and Childbirth 10, (2393-10-18).

Wen, L.M., Flood, V.M., Simpson, J.M., Rissel, C., Baur, L.A., 2010. Dietary behaviours during pregnancy: findings from first-time mothers in southwest Sydney, Australia. The International Journal of Behavioral Nutrition and Physical Activity 7, (5868-7-13).

Whitaker, K.M., Wilcox, S., Liu, J., Blair, S.N., Pate, R.R., 2016. Patient and provider perceptions of weight gain, physical activity, and nutrition counseling during pregnancy: a qualitative study. Women's Health Issues: Official Publication of the Jacobs Institute of Women's Health 26, 116-122.

Wilkinson, S.A., Miller, Y.D., Watson, B., 2009. Prevalence of health behaviours in pregnancy at service entry in a Queensland health service district. Australian and New Zealand Journal of Public Health 33, 228-233.

Zwanger!, 2015. Betrouwbare informatie en adviezen van verloskundigen, huisartsen en gynaecologen (Pregnant! Reliable information and advice from midwives, general practitioners and obstetricians) NVOG, KNOV, NHG, VVAH, Erfocentrum, KNMP, stichting Kind en Ziekenhuis, RI 
Baron, R., Martin, L., Gitsels-van der Wal, J.T., Noordman, J., Heymans, M.W., Spelten, E., Brugग J., Hutton, E.K. Health behaviour information provided to clients during midwife-led prenatal booking visits: findings from video analyses. Midwifery: 2017, 54(11), 7-17

\section{FIGURES AND TABLES}

Fig. 1. Flow chart of the inclusion and exclusion of clients and video recordings.

\section{4 midwife practices}

352 eligible clients

\section{П - 123 did not agree to participate}

229

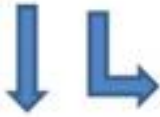

- $\mathbf{3 6}$ due to technical recording issues

193

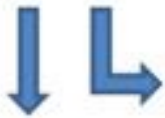

- $\mathbf{2 0}$ due to clients not having completed questionnaires with additional sociodemographic information, or the recordings not containing unique participating numbers

173 participants

Table 1. General characteristics of our study population of clients $(n=173)$.

\begin{tabular}{|c|c|c|}
\hline Client characteristics & & $\mathrm{N}(\%)$ \\
\hline \multirow{2}{*}{$\begin{array}{l}\text { Gestational age } \\
\text { (wks) }\end{array}$} & - Median (P5:P95) & $8(5: 13)$ \\
\hline & - Missing data & 7 \\
\hline \multirow{3}{*}{ Age } & - Mean(SD) & $29.03(4.03)$ \\
\hline & - Range & $20-40$ \\
\hline & - Missing data & 1 \\
\hline \multirow{2}{*}{ Education } & - Higher & $80(46.2)$ \\
\hline & - Low/medium & 93 (53.8) \\
\hline \multirow{2}{*}{ Parity } & - nulliparous & $89(51.4)$ \\
\hline & - multiparous & 84 (48.6) \\
\hline \multirow{2}{*}{ Ethnicity } & - Dutch & $135(78.0)$ \\
\hline & - Non-Dutch & $38(22.0)$ \\
\hline \multirow{5}{*}{ Weight at start of pregnancy } & - Normal & $81(56.3)$ \\
\hline & - Underweight & $8(5.6)$ \\
\hline & - Overweight & $40(27.8)$ \\
\hline & - Obese & $15(10.4)$ \\
\hline & - Missing data & 29 \\
\hline \multirow{3}{*}{ Takes folic acid } & - yes & $138(88.5)$ \\
\hline & - no & $18(11.5)$ \\
\hline & - Missing data & 17 \\
\hline Smokes & - no & 141 (85.5) \\
\hline
\end{tabular}


Baron, R., Martin, L., Gitsels-van der Wal, J.T., Noordman, J., Heymans, M.W., Spelten, E., Brug刃 J., Hutton, E.K. Health behaviour information provided to clients during midwife-led prenatal booking visits: findings from video analyses. Midwifery: 2017, 54(11), 7-17

\begin{tabular}{|l|l|l|}
\hline Client characteristics & & $\mathbf{N}(\%)$ \\
\hline & - yes & $24(14.5)$ \\
\cline { 2 - 3 } & - Missing data & 8 \\
\hline \multirow{3}{*}{ Partner smokes } & - no & $58(64.4)$ \\
\cline { 2 - 3 } & - yes & $32(35.6)$ \\
\cline { 2 - 3 } & - Missing data & 83 \\
\hline \multirow{3}{*}{ Consumes alcohol } & - no & $165(99.4)$ \\
\cline { 2 - 3 } & - yes & $1(0.6)$ \\
\cline { 2 - 3 } & - Missing data & 7 \\
\hline
\end{tabular}

'Missing data' refers to information which could neither be obtained from the client questionnaires nor the videos.

Table 2. Frequencies (+\%) of the extent of information on health behaviour topics, which clients were given by midwives during the prenatal booking visit.

\begin{tabular}{|c|c|c|c|c|}
\hline \multirow{2}{*}{$\begin{array}{l}\text { Health behaviour topic } \\
(N=173)\end{array}$} & \multirow{2}{*}{\begin{tabular}{|l|l|}
$\begin{array}{l}\text { Never } \\
\text { mentioned }\end{array}$ \\
$N(\%)$ \\
\end{tabular}} & \multirow{2}{*}{\begin{tabular}{|l|}
$\begin{array}{c}\text { Briefly } \\
\text { mentioned }\end{array}$ \\
$N(\%)$ \\
\end{tabular}} & \multirow{2}{*}{\begin{tabular}{|l|}
$\begin{array}{c}\text { Basically } \\
\text { explained }\end{array}$ \\
$N(\%)$
\end{tabular}} & \multirow{2}{*}{\begin{tabular}{|c|}
$\begin{array}{c}\text { Extensively } \\
\text { explained }\end{array}$ \\
$N(\%)$
\end{tabular}} \\
\hline & & & & \\
\hline \multicolumn{5}{|l|}{ Toxic substances } \\
\hline Alcohol & $7(4.0)$ & $158(91.3)$ & $5(2.9)$ & $3(1.7)$ \\
\hline Smoking in client & $8(4.6)$ & $141(81.5)$ & $20(11.6)$ & $4(2.3)$ \\
\hline Smoking in partner & $83(48.0)$ & $59(34.1)$ & $30(17.3)$ & $1(0.6)$ \\
\hline Vitamin A limitation & $53(30.6)$ & $62(35.8)$ & $50(28.9)$ & $8(4.6)$ \\
\hline \multicolumn{5}{|l|}{ N Nutrition } \\
\hline General nutritious diet & $66(38.2)$ & $78(45.1)$ & $29(16.8)$ & 0 \\
\hline Fish promotion & $157(90.8)$ & $13(7.5)$ & $3(1.7)$ & 0 \\
\hline Caffeine limitation & $155(89.6)$ & $14(8.1)$ & $4(2.3)$ & 0 \\
\hline \multicolumn{5}{|l|}{ Maternal weight } \\
\hline $\begin{array}{l}\text { Weight at start of } \\
\text { pregnancy }\end{array}$ & $18(10.4)$ & $90(52.0)$ & $63(36.4)$ & $2(1.2)$ \\
\hline $\begin{array}{l}\text { Recommended weight } \\
\text { gain }\end{array}$ & $159(91.9)$ & $8(4.6)$ & $6(3.5)$ & 0 \\
\hline \multicolumn{5}{|l|}{ Supplements } \\
\hline Folic acid & $17(9.8)$ & $101(58.4)$ & $48(27.7)$ & $7(4.0)$ \\
\hline Vitamin D & $151(87.3)$ & $19(11.0)$ & $3(1.7)$ & 0 \\
\hline \multicolumn{5}{|l|}{ Activities } \\
\hline Physical activity & $141(81.5)$ & $22(12.7)$ & $10(5.8)$ & 0 \\
\hline \begin{tabular}{|l|} 
Antenatal class \\
attendance \\
\end{tabular} & $131(75.7)$ & $32(18.5)$ & $9(5.2)$ & $1(0.6)$ \\
\hline
\end{tabular}

Table 3. Frequencies and percentages of the extent of information provision about folic acid, smoking and smoking in partner, respectively when the client does not take folic acid, smokes or when her partner smokes. 
Baron, R., Martin, L., Gitsels-van der Wal, J.T., Noordman, J., Heymans, M.W., Spelten, E., Brugh J., Hutton, E.K. Health behaviour information provided to clients during midwife-led prenatal booking visits: findings from video analyses. Midwifery: 2017, 54(11), 7-17

\begin{tabular}{|l|l|l|l|l|}
\hline \multirow{4}{*}{$\begin{array}{l}\text { Discussed and actual health } \\
\text { behaviour }\end{array}$} & \multicolumn{5}{|l|}{$\begin{array}{l}\text { Information provision on folic acid, smoking and smoking in } \\
\text { partner, respectively }\end{array}$} \\
\cline { 2 - 6 } & $\begin{array}{c}\text { Total } \\
\mathrm{N}\end{array}$ & $\begin{array}{l}\text { Briefly } \\
\text { mentioned } \\
\mathrm{N}(\%)\end{array}$ & $\begin{array}{l}\text { Basically } \\
\text { explained } \\
\mathrm{N}(\%)\end{array}$ & $\begin{array}{l}\text { Extensively } \\
\text { explained } \\
\mathrm{N}(\%)\end{array}$ \\
\hline No folic acid supplementation & 18 & $6(33.3)$ & $9(50)$ & $3(16.7)$ \\
\hline Client smokes & 24 & $2(8.3)$ & $19(79.2)$ & $3(12.5)$ \\
\hline Partner smokes & 32 & $2(6.3)$ & $29(90.6)$ & $1(3.1)$ \\
\hline
\end{tabular}

Table 4. Odds ratios (OR) and 95\% confidence intervals $(\mathrm{Cl})$ depicting the univariable relationships between client characteristics and the extent of information about a health behaviour topic, using Generalized Linear Mixed modelling (GLMM,) adjusted for practice and midwife level. The odds ratios $>1.0$ indicate more information provision than the reference group. The odds ratios for two dichotomous outcomes are shown: briefly mentioned/basically/extensively explained versus never mentioned: $\mathrm{OR}(1)$ and basically/extensively explained versus never/briefly mentioned: OR(2).

\begin{tabular}{|c|c|c|c|c|c|c|c|c|}
\hline \multirow{3}{*}{$\begin{array}{l}\text { Health } \\
\text { behaviour } \\
\text { topics } \\
(N=173)\end{array}$} & \multirow{2}{*}{\multicolumn{2}{|c|}{\begin{tabular}{|l|}
$\begin{array}{l}\text { Parity } \\
\text { (Multi:Ref) }\end{array}$ \\
Nulli
\end{tabular}}} & \multirow{2}{*}{\multicolumn{2}{|c|}{\begin{tabular}{|l|}
$\begin{array}{c}\text { Education } \\
\text { (High:Ref) }\end{array}$ \\
Low/Medium
\end{tabular}}} & \multicolumn{2}{|l|}{ Age } & \multirow{2}{*}{\multicolumn{2}{|c|}{\begin{tabular}{|l} 
BMI \\
(Not overweight:Ref) \\
Overweight/obese
\end{tabular}}} \\
\hline & & & & & Continuous & & & \\
\hline & $\begin{array}{l}\text { OR (1) } \\
(95 \% \mathrm{Cl})\end{array}$ & $\begin{array}{l}\text { OR (2) } \\
(95 \% \mathrm{Cl})\end{array}$ & $\begin{array}{l}\text { OR(1) } \\
(95 \% \mathrm{Cl})\end{array}$ & $\begin{array}{l}\text { OR (2) } \\
(95 \% \mathrm{Cl})\end{array}$ & $\begin{array}{l}\text { OR(1) } \\
(95 \% \mathrm{Cl})\end{array}$ & $\begin{array}{l}\text { OR (2) } \\
(95 \% \mathrm{Cl})\end{array}$ & $\begin{array}{l}\text { OR (1) } \\
(95 \% \mathrm{Cl})\end{array}$ & $\begin{array}{l}\text { OR (2) } \\
(95 \% \mathrm{Cl})\end{array}$ \\
\hline \multicolumn{9}{|l|}{$\begin{array}{l}\text { Toxic } \\
\text { substances }\end{array}$} \\
\hline Alcohol & NA & $1.0(0.4-2.8)$ & NA & $1.7(0.4-7.7)$ & NA & $1.0(0.9-1.2)$ & NA & $0.9(0.4-2.2$ \\
\hline $\begin{array}{c}\text { Vitamin A } \\
\text { limitation } \\
\end{array}$ & $1.7(0.8-3.6)$ & $2.7(1.6-4.5)$ & $1.2(0.6-2.2)$ & $1.0(0.6-1.6)$ & $1.0(0.8-1.1)$ & $0.9(1.9-1.0)^{*}$ & $0.8(0.4-1.5)$ & $1.9(1.1-3.5$ \\
\hline \multicolumn{9}{|l|}{ Nutrition } \\
\hline $\begin{array}{l}\text { General } \\
\text { nutritious } \\
\text { diet } \\
\end{array}$ & $2.5(1.3-4.9)$ & $1.8(0.9-3.6)$ & $1.7(1.0-2.9)$ & $1.7(0.9-3.3)$ & $0.9(0.9-1.0)$ & $0.9(0.9-1.0)^{*}$ & $0.6(0.3-1.2)$ & $0.6(0.2-1.6$ \\
\hline \begin{tabular}{|l|}
$\begin{array}{l}\text { Fish } \\
\text { promotion }\end{array}$ \\
\end{tabular} & $1.1(0.5-2.1)$ & NA & \begin{tabular}{|c|}
$5.4(1.9-$ \\
$15.7)$
\end{tabular} & NA & $1.0(1.0-1.1)$ & NA & $0.5(0.1-2.5)$ & NA \\
\hline $\begin{array}{l}\text { Caffeine } \\
\text { limitation }\end{array}$ & $2.1(0.9-4.6)$ & NA & $1.3(0.6-2.7)$ & NA & $1.0(1.0-1.1)$ & NA & $2.0(0.4-9.4)$ & NA \\
\hline \multicolumn{9}{|l|}{$\begin{array}{c}\text { Maternal } \\
\text { weight }\end{array}$} \\
\hline \begin{tabular}{|l|} 
Weight at \\
start of \\
pregnancy \\
\end{tabular} & $1.6(0.4-6.6)$ & $2.1(1.1-4.0)$ & $0.8(0.5-1.2)$ & $0.6(0.3-1.1)$ & $1.0(0.9-1.1)$ & $1.0(0.9-1.1)$ & $1.2(0.6-2.4)$ & $1.3(0.4-4.3$ \\
\hline $\begin{array}{l}\text { Recommend } \\
\text { ed weight } \\
\text { gain } \\
\end{array}$ & $8.4(8.0-8.8)$ & NA & $1.4(0.2-9.4)$ & NA & $0.9(0.8-1.0)^{*}$ & NA & $1.0(0.6-1.7)$ & NA \\
\hline \multicolumn{9}{|l|}{$\begin{array}{l}\text { Supplement } \\
s\end{array}$} \\
\hline Folic acid & NA & $0.7(0.6-0.9)$ & NA & $1.6(1.2-2.0)$ & NA & $1.0(1.0-1.1)$ & NA & $0.6(0.3-1.1)$ \\
\hline Vitamin D & $1.0(0.5-2.2)$ & NA & $0.5(0.2-1.3)$ & NA & $1.1(1.0-1.1)^{x}$ & NA & $0.6(0.1-2.5)$ & NA \\
\hline \multicolumn{9}{|l|}{ Activities } \\
\hline $\begin{array}{r}\text { Physical } \\
\text { activity }\end{array}$ & $1.8(0.5-6.5)$ & NA & $0.6(0.2-1.6)$ & NA & $1.0(0.9-1.1)$ & NA & $0.6(0.3-1.2)$ & NA \\
\hline \begin{tabular}{|l|} 
Antenatal \\
class \\
attendance \\
\end{tabular} & $1.4(1.0-2.1)^{*}$ & $1.0(0.4-2.2)$ & $2.3(1.5-3.8)$ & $2.5(1.4-4.4)$ & $1.0(0.9-1.0)$ & $0.9(0.9-1.0)^{*}$ & $0.7(0.5-1.1)$ & $0.4(0.2-0.9$ \\
\hline
\end{tabular}


Baron, R., Martin, L., Gitsels-van der Wal, J.T., Noordman, J., Heymans, M.W., Spelten, E., Brugh J., Hutton, E.K. Health behaviour information provided to clients during midwife-led prenatal booking visits: findings from video analyses. Midwifery: 2017, 54(11), 7-17

Bold: significant.

Ref: reference.

NA: not applicable due to small numbers.

'Smoking' and 'smoking in partner' not included in table, as there was a strong correlation with smoking status of client or partner.

* Significant: rounding error.

APPENDIX A

Assessment guide for assigning the extent of health behaviour discussion during videorecorded prenatal booking visits to a category.

\begin{tabular}{|c|c|c|c|c|}
\hline $\begin{array}{l}\text { Health } \\
\text { behaviour } \\
\text { topic }\end{array}$ & Briefly mentioned & Basically explained & Extensively explained & $\begin{array}{l}\text { Source of } \\
\text { information }\end{array}$ \\
\hline Folic acid & $\begin{array}{l}\text { Midwife asks whether } \\
\text { client is taking folic } \\
\text { acid (and/or if she } \\
\text { started before } \\
\text { conception) } \\
\text { Or } \\
\text { Midwife } \\
\text { recommends client } \\
\text { to take folic acid } \\
\text { Or } \\
\text { Client mentions } \\
\text { herself she is (not) } \\
\text { taking folic acid }\end{array}$ & $\begin{array}{l}\text { Mentions folic acid being } \\
\text { important for healthy baby, } \\
\text { but no mention of spina } \\
\text { bifida, nor until which week } \\
\text { folic acid should be } \\
\text { consumed. } \\
\text { Or } \\
\text { Only mentions until which } \\
\text { week folic acid should be } \\
\text { consumed, but not why folic } \\
\text { acid is important. }\end{array}$ & $\begin{array}{l}1 . \\
\text { Asks about folic acid use } \\
2 . \\
\text { Mentions that folic acid is } \\
\text { important for reducing the risk of } \\
\text { spina bifida. } \\
3 \text {. } \\
\text { Needs to be taken for at least the } \\
\text { first } 10 \text { weeks of pregnancy (and } \\
4 \text { weeks before conception, } \\
\text { although this information comes } \\
\text { too late for current pregnancy, so } \\
\text { is not obligatory) }\end{array}$ & $\begin{array}{l}\text { Zwanger! NOVG, } \\
\text { KNOV et al. (2014) }\end{array}$ \\
\hline Alcohol & $\begin{array}{l}\text { Midwife asks whether } \\
\text { client consumes } \\
\text { alcohol while } \\
\text { pregnant } \\
\text { Or } \\
\text { Midwife } \\
\text { recommends client } \\
\text { not to consume any } \\
\text { alcohol } \\
\text { Or } \\
\text { Client mentions } \\
\text { herself she is (not) } \\
\text { consuming alcohol }\end{array}$ & $\begin{array}{l}\text { Recommends avoiding } \\
\text { alcohol, and mentions that } \\
\text { alcohol can be harmful for } \\
\text { the foetus, but no } \\
\text { information on why. } \\
\text { (Sometimes midwife } \\
\text { explains there is no risk in } \\
\text { the first weeks as there is } \\
\text { no blood contact, will not } \\
\text { include this as 'minimally } \\
\text { explained', as this } \\
\text { information is not totally up- } \\
\text { to-date.) }\end{array}$ & $\begin{array}{l}1 . \\
\text { Asks about alcohol use } \\
2 . \\
\text { Possible consequences of alcohol } \\
\text { use during pregnancy (eg } \\
\text { preterm birth, Foetal Alcohol } \\
\text { Spectrum Disorders (FASD)) } \\
3 . \\
\text { Advises abstinence of alcohol } \\
\text { consumption during pregnancy } \\
4 . \\
\text { If client says yes, offers } \\
\text { advice/resources }\end{array}$ & $\begin{array}{l}\text { Zwanger! NOVG, } \\
\text { KNOV et al. (2014) }\end{array}$ \\
\hline $\begin{array}{l}\text { Physical } \\
\text { activity } \\
\text { promotion }\end{array}$ & $\begin{array}{l}\text { Midwife asks if client is } \\
\text { getting enough } \\
\text { exercise } \\
\text { Or } \\
\text { Midwife } \\
\text { recommends client } \\
\text { to continue } \\
\text { exercising } \\
\text { Or }\end{array}$ & $\begin{array}{l}\text { Recommends that client } \\
\text { continues to exercise } \\
\text { during pregnancy (eg more } \\
\text { vigorous exercise up till } 16 \\
\text { weeks) and which } \\
\text { exercises are beneficial } \\
\text { and less beneficial, but } \\
\text { nothing about the benefits } \\
\text { of doing exercises during }\end{array}$ & $\begin{array}{l}1 . \\
\text { Asks about or recommends } \\
\text { physical activity. } \\
2 \text {. } \\
\text { Mentions at least one benefit of } \\
\text { exercise (eg. control weight gain, } \\
\text { reduce chance of gestational } \\
\text { diabetes) } \\
3 .\end{array}$ & $\begin{array}{l}\text { Clinical Practice } \\
\text { Guidelines, } \\
\text { Antenatal care- } \\
\text { module 2, } \\
\text { Commonwealth of } \\
\text { Australia, } 2012\end{array}$ \\
\hline
\end{tabular}


Baron, R., Martin, L., Gitsels-van der Wal, J.T., Noordman, J., Heymans, M.W., Spelten, E., Brugh J., Hutton, E.K. Health behaviour information provided to clients during midwife-led prenatal booking visits: findings from video analyses. Midwifery: 2017, 54(11), 7-17

\begin{tabular}{|c|c|c|c|c|}
\hline $\begin{array}{l}\text { Health } \\
\text { behaviour } \\
\text { topic }\end{array}$ & Briefly mentioned & Basically explained & Extensively explained & $\begin{array}{l}\text { Source of } \\
\text { information }\end{array}$ \\
\hline & $\begin{array}{l}\text { Client mentions } \\
\text { herself she is } \\
\text { continuing to } \\
\text { exercise (in a } \\
\text { positive sense) } \\
\text { (Does not include } \\
\text { special pregnancy } \\
\text { classes for yoga, } \\
\text { fitness and } \\
\text { swimming) }\end{array}$ & pregnancy. & $\begin{array}{l}\text { Differentiates between safe sports } \\
\text { (eg. Swimming, cycling, walking, } \\
\text { fitness) and less safe sports } \\
\text { (Hockey, football, skiing), and } \\
\text { advises to reduce If there are } \\
\text { complaints. }\end{array}$ & \\
\hline Smoking & $\begin{array}{l}\text { Midwife asks whether } \\
\text { client smokes } \\
\text { Or } \\
\text { Midwife } \\
\text { recommends client } \\
\text { not to smoke } \\
\text { Or } \\
\text { Client mentions } \\
\text { herself she does } \\
\text { (not) smoke }\end{array}$ & $\begin{array}{l}\text { Mentions that smoking is } \\
\text { harmful for the foetus (but } \\
\text { not why, or does not offer } \\
\text { resources/advice), and } \\
\text { advises her to stop or at } \\
\text { least reduce }\end{array}$ & $\begin{array}{l}1 . \\
\text { Asks about current as well as past } \\
\text { smoking. } \\
2 . \\
\text { Mentions possible consequences } \\
\text { of smoking (eg. preterm birth, } \\
\text { low birth weight, asthma) } \\
3 . \\
\text { If smoking, gives advice and refers } \\
\text { to other resources for help in } \\
\text { cessation or reduction }\end{array}$ & $\begin{array}{l}\text { Zwanger! NOVG, } \\
\text { KNOV et al. (2014) }\end{array}$ \\
\hline $\begin{array}{l}\text { Smoking in } \\
\text { partner }\end{array}$ & $\begin{array}{l}\text { Midwife asks whether } \\
\text { partner smokes } \\
\text { Or } \\
\text { Midwife } \\
\text { recommends partner } \\
\text { not to smoke or not } \\
\text { smoke inside } \\
\text { Or } \\
\text { Partner mentions } \\
\text { himself that he does } \\
\text { (not) smoke }\end{array}$ & $\begin{array}{l}\text { Mentions that passive } \\
\text { smoking is harmful for the } \\
\text { foetus (but not why) and } \\
\text { recommends that partner } \\
\text { stops, reduces smoking, or } \\
\text { only smokes outside. }\end{array}$ & $\begin{array}{l}1 . \\
\text { Asks about current as well as past } \\
\text { smoking in partner } \\
2 . \\
\text { Mentions possible consequences } \\
\text { of passive smoking (eg. preterm } \\
\text { birth, low birth weight, asthma) } \\
3 . \\
\text { If smoking, gives advice and refers } \\
\text { to other resources for help }\end{array}$ & \\
\hline $\begin{array}{l}\text { Pre-Pregnancy } \\
\text { weight/ } \\
\text { weight at } \\
\text { start of } \\
\text { pregnancy }\end{array}$ & $\begin{array}{l}\text { Midwife asks client } \\
\text { about her height and } \\
\text { pre-pregnancy } \\
\text { weight, or weighs } \\
\text { client in the midwife } \\
\text { practice. } \\
\text { Or } \\
\text { Does not weigh or } \\
\text { ask about weight, or } \\
\text { mention her BMI, but } \\
\text { mentions something } \\
\text { about her weight } \\
\text { status. }\end{array}$ & $\begin{array}{l}\text { Ascertains client's BMI and } \\
\text { mentions something about } \\
\text { her weight status, such as } \\
\text { telling her that her weight is } \\
\text { normal, or that her BMI is } \\
\text { too high and she will need } \\
\text { extra glucose tests, or } \\
\text { ultrasounds. } \\
\text { Or } \\
\text { Midwife asks client about } \\
\text { her height and pre- } \\
\text { pregnancy weight, or } \\
\text { weighs client in the midwife } \\
\text { office and without } \\
\text { mentioning actual BMI, } \\
\text { mentions something about } \\
\text { her weight status. }\end{array}$ & $\begin{array}{l}1 . \\
\text { Ascertains BMI before or at } \\
\text { beginning of pregnancy } \\
2 . \\
\text { Depending on weight status of } \\
\text { client, explains some risks of pre- } \\
\text { pregnancy underweight (eg. } \\
\text { preterm or SGA) or } \\
\text { overweight/obesity (eg. pre- } \\
\text { eclampsia, gestational diabetes, } \\
\text { SGA, LGA) } \\
\text { Or } \\
\text { Mentions several benefits of } \\
\text { normal weight at the start of } \\
\text { pregnancy, (such as decreased } \\
\text { risk of SGA, gestational diabetes, } \\
\text { pre-eclampsia, etc) }\end{array}$ & $\begin{array}{l}\text { Clinical Practice } \\
\text { Guidelines, } \\
\text { Antenatal care- } \\
\text { module 1, } \\
\text { Commonwealth of } \\
\text { Australia, } 2012\end{array}$ \\
\hline $\begin{array}{l}\text { Recommended } \\
\text { weight gain }\end{array}$ & $\begin{array}{l}\text { Gives general } \\
\text { recommended } \\
\text { weight gain over } \\
\text { pregnancy (eg. 12- } \\
15 \mathrm{~kg} \text { ) }\end{array}$ & $\begin{array}{l}\text { Gives the recommended } \\
\text { weight gain over pregnancy } \\
\text { according to BMI, without } \\
\text { any additional explanation } \\
\text { or advice }\end{array}$ & $\begin{array}{l}1 . \\
\text { Explains recommended weight } \\
\text { gain over pregnancy according to } \\
\text { pre-pregnancy BMI weight } \\
\text { category }\end{array}$ & $\begin{array}{l}\text { Clinical Practice } \\
\text { Guidelines, } \\
\text { Antenatal care- } \\
\text { module } 1, \\
\text { Commonwealth of }\end{array}$ \\
\hline
\end{tabular}


Baron, R., Martin, L., Gitsels-van der Wal, J.T., Noordman, J., Heymans, M.W., Spelten, E., Brugh J., Hutton, E.K. Health behaviour information provided to clients during midwife-led prenatal booking visits: findings from video analyses. Midwifery: 2017, 54(11), 7-17

\begin{tabular}{|c|c|c|c|c|}
\hline \multirow{3}{*}{\begin{tabular}{|l} 
Health \\
behaviour \\
topic
\end{tabular}} & \multirow{3}{*}{ Briefly mentioned } & \\
\hline & & Basically explained & Extensively explained & $\begin{array}{l}\text { Source of } \\
\text { information }\end{array}$ \\
\hline & & $\begin{array}{l}\text { Or } \\
\text { General recommended } \\
\text { weight gain, plus why it is } \\
\text { important to maintain } \\
\text { adequate weight gain, or } \\
\text { advice on how to maintain } \\
\text { adequate weight gain. }\end{array}$ & $\begin{array}{l}2 . \\
\text { Gives at least one benefit of } \\
\text { adhering to recommended } \\
\text { weight gain } \\
\text { 3. } \\
\text { Gives advice on maintaining } \\
\text { healthy weight gain during } \\
\text { pregnancy. }\end{array}$ & Australia, 2012 \\
\hline Nutritious diet & $\begin{array}{l}\text { Mentions that a } \\
\text { healthy diet is } \\
\text { important without } \\
\text { examples of healthy } \\
\text { nutrition or why it is } \\
\text { important } \\
\text { Or } \\
\text { Only asks if client } \\
\text { has a healthy diet } \\
\text { without further } \\
\text { explanation. } \\
\text { Or } \\
\text { Asks clients if she is } \\
\text { eating enough fruits } \\
\text { and vegetables } \\
\text { without further } \\
\text { explanation. } \\
\text { Or } \\
\text { Only advises eating } \\
\text { a healthy and/or } \\
\text { varied diet. } \\
\text { (Does not include } \\
\text { telling client to wash } \\
\text { all fruits and } \\
\text { vegetables, or not to } \\
\text { let them expire) }\end{array}$ & $\begin{array}{l}\text { Mentions it's important to eat } \\
\text { a healthy and varied diet, } \\
\text { and names at least } \\
\text { fruits/vegetables, as well as } \\
\text { another nutrition type, such } \\
\text { as dairy products or meats } \\
\text { to promote health (not to } \\
\text { avoid infectious diseases). } \\
\text { Or } \\
\text { Mentions it's important to } \\
\text { eat a healthy and varied } \\
\text { diet and can supplement } \\
\text { diet with extra nutrients } \\
\text { from multivitamins for } \\
\text { pregnant women. }\end{array}$ & $\begin{array}{l}\text { 1. } \\
\text { Mentions at least one benefit of a } \\
\text { nutritious diet during pregnancy. } \\
2 . \\
\text { Recommends not to eat too much } \\
\text { (not for two) and less saturated } \\
\text { fats/sugars (unhealthy foods). } \\
\text { 3. } \\
\text { Eat a varied diet, choose foods } \\
\text { from these five different } \\
\text { categories: } 1 \text {.fruits and } \\
\text { vegetables, } 2 \text {. oils and fats, } 3 . \\
\text { liquids, } 4 \text {. potatoes, beans and } \\
\text { grains and } 5 \text {. meats, fish and } \\
\text { dairy products. (Can also refer to } \\
\text { Schijf van Vijf on } \\
\text { 'Voedingscentrum' website, and } \\
\text { name a few food categories) }\end{array}$ & $\begin{array}{l}\text { Zwanger! NOVG, } \\
\text { KNOV et al. (2014) } \\
\text { refers to } \\
\text { voedingscentrum } \\
\text { 'schijf van vijf' }\end{array}$ \\
\hline $\begin{array}{l}\text { Caffeine } \\
\text { consumption }\end{array}$ & $\begin{array}{l}\text { Advises client not to } \\
\text { drink too much } \\
\text { caffeine in the form } \\
\text { of coffee, coke } \\
\text { (cola), or tea. } \\
\text { Or } \\
\text { Does not mention } \\
\text { where caffeine is } \\
\text { found, but says only } \\
\text { about coffee (for } \\
\text { example) that client } \\
\text { can have a max no. } \\
\text { of cups per day. }\end{array}$ & $\begin{array}{l}\text { Give advice about where } \\
\text { caffeine is found (eg. } \\
\text { coffee, tea, coke (cola)), } \\
\text { and how much to } \\
\text { drink/consume per day (eg. } \\
\text { max four cups of coffee per } \\
\text { day) }\end{array}$ & $\begin{array}{l}\text { 1. } \\
\text { Explains which products contain } \\
\text { caffeine } \\
2 . \\
\text { Gives some advice on how much } \\
\text { per day (such as max } 4 \text { cups } \\
\text { coffee) } \\
3 . \\
\text { Explains some of the risks } \\
\text { associated with too much } \\
\text { caffeine (such as low birth } \\
\text { weight). }\end{array}$ & \begin{tabular}{|l} 
\\
Ree et al., 2015 \\
- \\
NICE Routine care \\
for the healthy \\
pregnant woman, \\
Clinical guideline, \\
2008 \\
- \\
Voedingen \\
Zwangerschap, \\
2015 \\
(Voedingscentrum) \\
\end{tabular} \\
\hline $\begin{array}{l}\text { Fish (to } \\
\text { promote } \\
\text { health) }\end{array}$ & $\begin{array}{l}\text { Advises client to eat } \\
\text { fish } \\
\text { Or } \\
\text { Tells clients that fish } \\
\text { is healthy during } \\
\text { pregnancy } \\
\text { Or } \\
\end{array}$ & $\begin{array}{l}\text { Tells clients that fish } \\
\text { consumption is healthy } \\
\text { during pregnancy (but not } \\
\text { why) and names several } \\
\text { fish which are good (and } \\
\text { safe) to eat during } \\
\text { pregnancy. }\end{array}$ & $\begin{array}{l}1 . \\
\text { Explains why fish is beneficial } \\
\text { (eg.contains omega } 3 \text { fatty acids } \\
\text { which is beneficial for brain } \\
\text { development of foetus, source of } \\
\text { vitamin D) } \\
2 .\end{array}$ & \begin{tabular}{|l|} 
\\
Starling,2015 \\
(systematic review) \\
- \\
EuropeanFood Safety \\
$\quad$ Authority (2014) \\
\end{tabular} \\
\hline
\end{tabular}


Baron, R., Martin, L., Gitsels-van der Wal, J.T., Noordman, J., Heymans, M.W., Spelten, E., Brugh J., Hutton, E.K. Health behaviour information provided to clients during midwife-led prenatal booking visits: findings from video analyses. Midwifery: 2017, 54(11), 7-17

\begin{tabular}{|c|c|c|c|c|}
\hline $\begin{array}{l}\text { Health } \\
\text { behaviour } \\
\text { topic }\end{array}$ & Briefly mentioned & Basically explained & Extensively explained & $\begin{array}{l}\text { Source of } \\
\text { information }\end{array}$ \\
\hline & $\begin{array}{l}\text { Advises client to take } \\
\text { fish oil (eg in } \\
\text { capsules) } \\
\text { (Not about avoiding } \\
\text { pre-packaged fish, } \\
\text { also does not include } \\
\text { telling client she is } \\
\text { allowed to eat fish) }\end{array}$ & $\begin{array}{l}\text { Or } \\
\text { Tells client that fish is } \\
\text { healthy and advises how } \\
\text { often to eat fatty fish per } \\
\text { week (eg. twice) }\end{array}$ & $\begin{array}{l}\text { Gives examples of good fish to eat } \\
\text { and fish to be avoided (due to } \\
\text { mercury) } \\
3 \text {. } \\
\text { Explains how much can be eaten } \\
\text { (eg per week) }\end{array}$ & $\begin{array}{l}\text { Voedingen } \\
\text { Zwangerschap, } \\
2015 \\
\text { (Voedingscentrum) }\end{array}$ \\
\hline Vitamin A & $\begin{array}{l}\text { Mentions that the } \\
\text { client needs to avoid } \\
\text { or minimize } \\
\text { consumption of } \\
\text { vitamin A or liver } \\
\text { products. } \\
\text { Or } \\
\text { Asks client if she is } \\
\text { avoiding or } \\
\text { minimizing } \\
\text { consumption of } \\
\text { vitamin A or liver } \\
\text { products. } \\
\text { Or } \\
\text { Mentions she should } \\
\text { avoid liver products } \\
\text { as well as how much } \\
\text { per day, without } \\
\text { mentioning 'vitamin } \\
\text { A'. }\end{array}$ & $\begin{array}{l}\text { Mentions only } 2 \text { out of } 3 \text { of } \\
\text { the criteria of 'extensively } \\
\text { explained', such as which } \\
\text { products contain vitamin A } \\
\text { and how much one can } \\
\text { have per day, but not } \\
\text { explaining why it is } \\
\text { dangerous for the unborn } \\
\text { baby. }\end{array}$ & $\begin{array}{l}\text { 1. } \\
\text { Explains that Vitamin A } \\
\text { supplementation can cause birth } \\
\text { defects } \\
2 \text {. } \\
\text { Avoid consumption of Vitamin A } \\
\text { tablets, liver and liver products } \\
3 . \\
\text { Liver products such as liverpaté, } \\
\text { limit to one sandwich a day }\end{array}$ & $\begin{array}{l}\text { Zwanger! NOVG, } \\
\text { KNOV et al. (2014) }\end{array}$ \\
\hline Vitamin D & $\begin{array}{l}\text { Mentions that } \\
\text { supplementary } \\
\text { vitamin } D \text { is } \\
\text { recommended } \\
\text { Or } \\
\text { Asks if client is } \\
\text { taking } \\
\text { supplementary } \\
\text { vitamin } D \text { (within a } \\
\text { multivitamin). } \\
\text { (This does not } \\
\text { include asking if the } \\
\text { client is taking a } \\
\text { multivitamin, without } \\
\text { mentioning vitamin } \\
\text { D) }\end{array}$ & $\begin{array}{l}\text { Recommends taking extra } \\
\text { vitamin D (in a multivitamin } \\
\text { supplement) with brief } \\
\text { explanation why. } \\
\text { Or } \\
\text { Recommends taking extra } \\
\text { vitamin D (in a multivitamin } \\
\text { supplement), and explains } \\
\text { which sources contain } \\
\text { vitamin D. }\end{array}$ & $\begin{array}{l}\text { Gives at least } 3 \text { of these } \\
\text { explanations: } \\
\text { 1. } \\
\text { No agreement on routine Vitamin } \\
\text { D supplementation, NICE } \\
\text { guidelines and Dutch Health } \\
\text { committee advise } 10 \mathrm{mg} \text { of } \\
\text { vitamin D each day during } \\
\text { pregnancy } \\
\text { 2. } \\
\text { Explain the importance of vitamin } \\
\text { D during pregnancy and one or } \\
\text { more possible consequences of } \\
\text { vitamin D deficiency (such as } \\
\text { bone/teeth development in child, } \\
\text { pre-eclampsia in mother) } \\
\text { 3. } \\
\text { General consensus: advise Vit D } \\
\text { supplementation in women with } \\
\text { limited sun exposure, BMl>30, or } \\
\text { dark skin } \\
4 \text {. } \\
\text { Food sources containing vit D (eg } \\
\text { salmon, mackerel, meat and } \\
\text { eggs) }\end{array}$ & $\begin{array}{l}\text { Zwanger! NOVG, } \\
\text { KNOV et al. (2014) } \\
- \\
\text { Clinical Practice } \\
\text { Guidelines, } \\
\text { Antenatal care- } \\
\text { module 1, } \\
\text { Commonwealth of } \\
\text { Australia, } 2012\end{array}$ \\
\hline Benefits of & Asks if client is taking/ & Recommends or mentions at & 1. & Zwanger! NOVG, \\
\hline
\end{tabular}


Baron, R., Martin, L., Gitsels-van der Wal, J.T., Noordman, J., Heymans, M.W., Spelten, E., Brugg J., Hutton, E.K. Health behaviour information provided to clients during midwife-led prenatal booking visits: findings from video analyses. Midwifery: 2017, 54(11), 7-17

nivel

\begin{tabular}{|c|c|c|c|c|}
\hline $\begin{array}{l}\text { Health } \\
\text { behaviour } \\
\text { topic }\end{array}$ & Briefly mentioned & Basically explained & Extensively explained & $\begin{array}{l}\text { Source of } \\
\text { information }\end{array}$ \\
\hline $\begin{array}{l}\text { antenatal } \\
\text { class } \\
\text { attendance }\end{array}$ & $\begin{array}{l}\text { will take any } \\
\text { antenatal classes } \\
\text { Or } \\
\text { Recommends that } \\
\text { client takes antenatal } \\
\text { classes } \\
\text { Or } \\
\text { Only refers to } \\
\text { website or folders for } \\
\text { antenatal classes. }\end{array}$ & $\begin{array}{l}\text { least one type of antenatal } \\
\text { class and refers client to } \\
\text { website or other sources } \\
\text { where antenatal classes } \\
\text { can be found, but no } \\
\text { mention of benefits of } \\
\text { taking antenatal classes. }\end{array}$ & $\begin{array}{l}\text { Mentions at least one type of } \\
\text { antenatal class } \\
2 . \\
\text { Mentions one or more benefits of } \\
\text { antenatal classes } \\
3 \text {. } \\
\text { Refers to resources (eg folders, } \\
\text { websites) about antenatal } \\
\text { classes } \\
\text { (Does not include breastfeeding } \\
\text { classes; If this is about a regular } \\
\text { non-pregnancy class which } \\
\text { promotes physical activity, such } \\
\text { as swimming, categorize under } \\
\text { 'physical activity'.) }\end{array}$ & KNOV et al. (2014) \\
\hline
\end{tabular}

Assessment guide with criteria for assigning the extent of discussion of relevant health behaviour topics during the prenatal booking visit to the four categories 'never mentioned', 'briefly mentioned', 'basically explained' and 'extensively explained'. The category 'never mentioned' is not included here, as its sole criteria entails the topic never arising at all during the prenatal visit. 